\title{
National Symposium on Immigrant Health in Canada
}

\author{
An Overview
}

\author{
Jenny Gold, MHSc ${ }^{1}$ \\ Marie DesMeules, $\mathrm{MSc}^{2}$
}

$\mathrm{E}$ thnicity and migration are recognized as factors that determine health due to biological, cultural, social, and lifestyle factors. ${ }^{1-3}$ The most recent census results show that the ethnocultural profile of Canada is increasingly diverse. In 2001, approximately 5.4 million Canadians, or $18.4 \%$ of the total population, were born outside of the country, an increase from $17.4 \%$ in 1996 . This proportion is higher than most other countries worldwide, with the exception of Australia where, in 2001 , about $22 \%$ of the total population was foreign-born. In the United States, immigrants represent about $11 \%$ of the total population. ${ }^{4}$ Immigrants represent a very diverse population in terms of ethnicity, cultural and sociodemographic characteristics. Immigrants to Canada come from all parts of the world, although a large proportion of more recent immigrants come from Asia and the Middle East in the last decade (58\% in 1991-2001). 4.5

Knowledge of the unique patterns of health and health care needs of immigrants is currently somewhat limited in Canada. Considering the very diverse ethnocultural profile of the Canadian population, as well as the size of the immigrant population, national consensus is needed on current knowledge and research priorities with respect to determinants of health, health status, and health services utilization among immigrants in Canada. These efforts would help develop more targeted policies and programs aimed at reducing existing health disparities. In light of this need, a National Symposium on Immigrant Health was held on March 25, 2003, in Ottawa, Ontario as part of a broader Conference on Migration and Health. The Symposium was a collaborative initiative among Health Canada, Citizenship and Immigration Canada, academic experts, and the Canadian Population Health Initiative (Canadian Institute for Health Information).

The Symposium was a key component of the national research initiatives on immigrant health and health service utilization. Health Canada, Citizenship and Immigration Canada, and provincial partners are currently collaborating on immigrant health assessment research projects sponsored by the Canadian Population Health Initiative and Health Canada. The objectives of this national consultation symposium were to contribute to this important area of population health by reviewing current knowledge on immigrant health in Canada, and by identifying priority research areas and policy needs. In view of the inherent multidisciplinary nature of immigrant health assessment, the complex relationships between social determinants of health and migration, and the international nature of immigration, the symposium speakers and participants included researchers, policymakers, and medical professionals with expertise in immigration and health from Canada and the United States. These proceedings summarize the presentations and insightful discussions, as well as the research and policy directions arising from this symposium.

\footnotetext{
Population Health Assessment Section, Surveillance Risk Assessment Division, Centre for Chronic Disease Prevention and Control, Health Canada, Ottawa, ON

1. Analyst

2. Chief

Correspondence: Ms. Marie DesMeules, Chief, Population Health Assessment Section, Surveillance Risk Assessment Division, Centre for Chronic Disease Prevention and Control, Health Canada, 120 Colonnade Road, AL 6702A, Ottawa, ON K1A 0K9, Tel: 613-957-0577, Fax: 613-941-2057, E-mail: marie_desmeules@hc-sc.gc.ca
}

\section{ACKNOWLEDGEMENTS}

The Canadian Population Health Initiative of the Canadian Institute for Health Information, Health Canada, and Citizenship and Immigration Canada sponsored the National Symposium on Immigrant Health in Canada held on March 25, 2003, in Ottawa, Ontario. The Symposium was held collaboratively with the Migration Health Conference, Towards a Migration Framework for the $21^{\text {st }}$ Century, which took place from March 25-26, 2003.

\section{REFERENCES}

1. Health Canada. Towards a Healthy Future: Second Report on the Health of Canadians. Ottawa, ON: Health Canada, 1999.

2. Hyman I. Immigration and Health. Health Policy Working Paper Series. Working paper 01-05. Ottawa, ON: Health Canada, September 2001.

3. Kinnon D. Canadian Research on Immigration and Health - An Overview. Ottawa, ON: Health Canada, 1999.

4. Statistics Canada. 2001 Census: Analysis Series, Canada's Ethnocultural Portrait - The Changing Mosaic. Ottawa, ON: Statistics Canada, 2003.

5. Citizenship and Immigration Canada. Facts and Figures - Immigration Overview. Ottawa, ON: Citizenship and Immigration Canada, 2002. 